\title{
Mineralogical, micromorphological and geochemical evolution of the facies from the bauxite deposit of Barro Alto, Central Brazil
}

\author{
Fábio Soares de Oliveira ${ }^{a, b, *}$, Angélica Fortes Drummond Chicarino Varajão ${ }^{\text {, }}$ \\ César Augusto Chicarino Varajão a , Bruno Boulangé ${ }^{c}$, Caroline Cibele Vieira Soares ${ }^{a}$ \\ a Departamento de Geologia, Universidade Federal de Ouro Preto, Campus Morro do Cruzeiro, s/n, Ouro Preto, 35400-000, MG, Brazil \\ b Departamento de Geografia, Instituto de Geociências, Universidade Federal de Minas Gerais, UFMG. Av. Antônio Carlos, 6627, Belo Horizonte, 31270-901, MG, Brazil \\ c Museé de la Bauxite, Tourves, France
}

\section{A R T I C L E I N F O}

\section{Article history:}

Received 22 May 2011

Received in revised form 8 January 2013

Accepted 14 January 2013

\section{Keywords:}

Bauxite

Mineralogy

Geochemistry

Micromorphology

Evolution

Alteration facies

\begin{abstract}
A B S T R A C T
The hydrolytic alteration of anorthosite from the Barro Alto Stratiform Mafic-Ultramafic Complex (Central Brazil) caused the formation of an isalteritic bauxite. Petrological studies using X-ray diffraction (XRD), X-ray fluorescence (XRF), mass balance calculation and micromorphological description via optical microscopy were undertaken to understand the evolution of the bauxitic massif. The results suggest the transformation of the isalteritic bauxite (F1) into varied alteration facies and their filiations as follows: the formation of semi-compact massive bauxite (F2) and compact massive bauxite (F3) by the recrystallisation of gibbsite filing voids, resulting in enriched absolute aluminium ( 9 and 25\%, respectively); the formation of laminar bauxite (F4) and fragmentary bauxite (F5), which is associated with different types of fragmented massive duricrust, such as those formed by mechanical (root activity, tectonics, etc.) and geochemical (dissolution of gibbsite, kaolinite neoformation, etc.) processes; the formation of palaeopediment bauxite (F6); the formation of degraded clay with gibbsitic nodules (F7), which is associated with the resilicification process by the oscillation of the water table caused by changes in the shapes of slopes and the cycling of silica by vegetation. Isalteritic clay (F8) facies directly derived from the anorthosite are also found. The relationship between the facies reflects the polygenetic evolution of the bauxitic massif.
\end{abstract}

Crown Copyright @ 2013 Published by Elsevier B.V. All rights reserved.

\section{Introduction}

The bauxite deposit of Barro Alto constitutes a reserve of nearly 160 million tons (Reis, 2007; Veiga and Girodo, 2008) and is located in the midwestern region of Goias, Brazil (Fig. 1A). The deposit developed from the anorthosites of the Superior Series of the Barro Alto Stratiform Mafic-Ultramafic Complex (CBA) in the Neoproterozoic Brasília Belt in Tocantins Province (Almeida et al., 1981). This bauxitisation process from anorthosite has been recently described by Oliveira et al. (2009, 2011). Before these studies, the only known occurrence of bauxite originating from anorthosite in the world was in Port Loko, Sierra Leone (Hains, 2005). However, the bauxitisation process from this deposit has not yet been described. In Brazil, a country with the largest reserves of bauxite in the world, there was no knowledge of another deposit in the central region of the country (Melfi, 1997).

The macro-morphological distribution and geomorphological evolution of the Barro Alto bauxite (Oliveira et al., 2009) and its petrological study (Oliveira et al., 2011) revealed different facies. The main goal of

\footnotetext{
* Corresponding author at: Departamento de Geografia, Instituto de Geociências, Universidade Federal de Minas Gerais, UFMG. Av. Antônio Carlos, 6627, Belo Horizonte, 31270-901, MG, Brazil. Tel.: + 5531 75151177; fax: +55 3135591606.

E-mail address: fabiosolos@gmail.com (F.S. Oliveira).
}

this study is the investigation of the mineralogical, micromorphological and geochemical evolution of the Barro Alto bauxite deposit. The results obtained from this study are important from both scientific and economic perspectives; scientifically, there are no studies that characterise the evolution of bauxite deposits originating from anorthosites, and economically, the Barro Alto bauxite would alter the Brazilian mineral economy, providing Brazil's midwest with a great potential source for the production of aluminium ore.

\section{Materials and methods}

\subsection{Study area}

The Barro Alto bauxite massif's regional geomorphology is composed of three sets of ranges: the Santa Barbara, the Laguna and the Grande (Fig. 1B). The bauxite massif is located in the Grande range and is compartmentalised into two hills, Torre and Buraco (Fig. 1C), which have altitudes of $1500 \mathrm{~m}$ and $1300 \mathrm{~m}$, respectively. Such altitudes are higher compared with the altitude of the surrounding morphology, which varies between $550 \mathrm{~m}$ and $900 \mathrm{~m}$.

The climate in the Barro Alto region is tropical, with an average annual rainfall of $1600 \mathrm{~mm}$ and a mean air temperature of $25^{\circ} \mathrm{C}$ and two defined seasons (dry winter and humid summer). The vegetation 


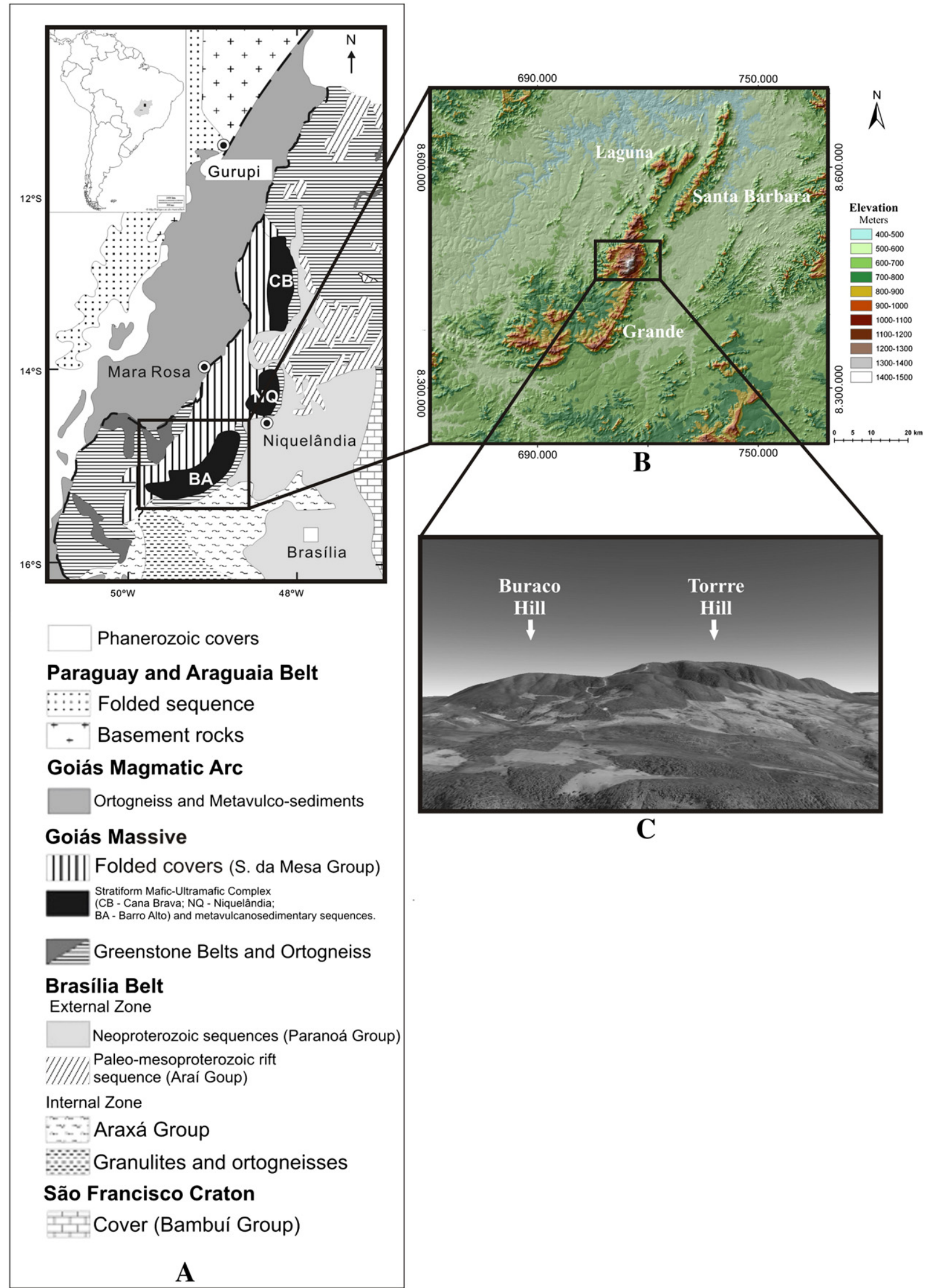

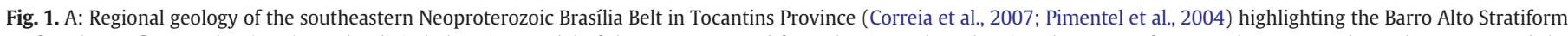

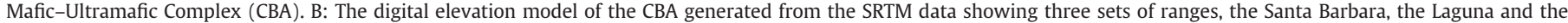
Grande, as well as the bauxitic massif of Barro Alto. C: Image from Google Earth (with $2 \times$ vertical zoom) showing the Torre and Buraco Hills. 
consists of cerrado fields (Brasil et al., 1981), which are preserved at elevations above $1000 \mathrm{~m}$. Agricultural activity is intense in the lowlands.

\subsection{Sampling and laboratory analysis}

Based on previous fieldwork, which defined the bauxite macromorphological facies and their lateral distributions (Oliveira et al., 2009), 98 samples of alteration facies and 8 samples of fresh rock were collected for this study. The samples were collected from cores drilled through the regolith and open pits in three topos sequences.

The description of profiles, including the identification of alteration facies, was performed using the same terms used in the reference studies (Boulangé, 1984; Nahon, 1991; Tardy, 1993). The description of the samples was based on macromorphological aspects, such as colour (Munsell, 1975), texture and minerals, and was performed with a magnifying lens (20× magnification).

The major and minor element concentrations of silicon ( $\mathrm{Si}$ ), sodium $(\mathrm{Na})$, potassium $(\mathrm{K})$, manganese $(\mathrm{Mn})$, magnesium $(\mathrm{Mg})$, calcium $(\mathrm{Ca})$, iron $(\mathrm{Fe})$, aluminium $(\mathrm{Al})$, titanium $(\mathrm{Ti})$ and phosphorus $(\mathrm{P})$ were determined using X-ray fluorescence (XRF) (Magix PANalytical Philips spectrometer equipped with a PW2540 autosampler), and the oxide contents were reported (in wt.\%).

The mineralogical compositions of the powder samples were obtained by X-ray diffraction (XRD) using an X'Pert PANalytical diffractometer with CuK $\alpha$ radiation in the range of $2^{\circ}$ to $70^{\circ} 2 \theta$ and at a speed of $0.6^{\circ} / \mathrm{min}$. The XRD patterns were interpreted using HighScore X'Pert Plus software and compared with known patterns found in the literature (Brindley and Brown, 1980).

Optical microscopic investigations were conducted on 155 thin sections of undisturbed samples using a Zeiss trinocular optical microscope (Axiophot model) equipped with an integrated digital camera. The guidelines of Bullock et al. (1985) and Delvigne (1998) were used for the micromorphological descriptions.

For the morphological characterisation of the kaolinite particles, specimens were prepared via dispersed sampling for analytical transmission electron microscopy (ATEM - Tecnai - G2-20-FEI 2006). A highly diluted suspension of the clay particles $<2-\mu \mathrm{m}$ in size from the clay facies was prepared in distilled water, and the clay particles were dispersed using an ultrasonic treatment. A drop of the suspension was deposited onto a carbon-coated grid and dried at room temperature.

Bulk density analysis was performed on representative samples of five facies (F1, F2, F3, F8 and F9) and fresh rock (R), with 25 repetitions for each, according to the method proposed by Millot and Bonifas (1955).

Cartographic analysis was performed by exploring a digital elevation model (DEM) obtained from the Shuttle Radar Topography Mission (SRTM) using the ArcGis 9.3 software program (ESRI). We also used illustrative images from Google Earth.

\subsection{Statistical analysis}

For elemental chemical analysis, we calculated the average total number of samples from each facies and their standard deviation (expressed with the \pm symbol).

To verify the gains and losses in geochemical mass between the facies, we applied an isovolumetric calculation (Millot and Bonifas, 1955) using the following equation:

$k_{\mathrm{j}}=\left\{\left[\left(\begin{array}{ll}C_{\mathrm{j}, \mathrm{w}} & d_{\mathrm{j}, \mathrm{w}}\end{array}\right) /\left(C_{\mathrm{j}, \mathrm{p}} d_{\mathrm{j}, \mathrm{p}}\right)\right]-1\right\} 100$

where $k_{\mathrm{j}}$ is the enrichment factor or loss of an element, $C_{\mathrm{j}, \mathrm{w}}$ is the concentration of element $\mathrm{j}$ in the alteration facies $\mathrm{w}, C_{\mathrm{j}, \mathrm{p}}$ is the concentration of element $\mathrm{j}$ in the parent material $\mathrm{p}, d_{\mathrm{j}, \mathrm{w}}$ is the bulk density of the alteration facies and $d_{\mathrm{j}, \mathrm{p}}$ is the bulk density of the parent material. In the results, negative values indicate the loss of an element and positive values indicate the gain of an element (Millot and Bonifas, 1955).

\section{Results}

3.1. Macromorphology, mineralogy, micromorphology and geochemistry of the facies

From field investigations (Oliveira et al., 2009) and mineralogical, geochemical and micromorphological studies, nine facies of alteration were defined in the bauxitic massif of Barro Alto (Fig. 2).
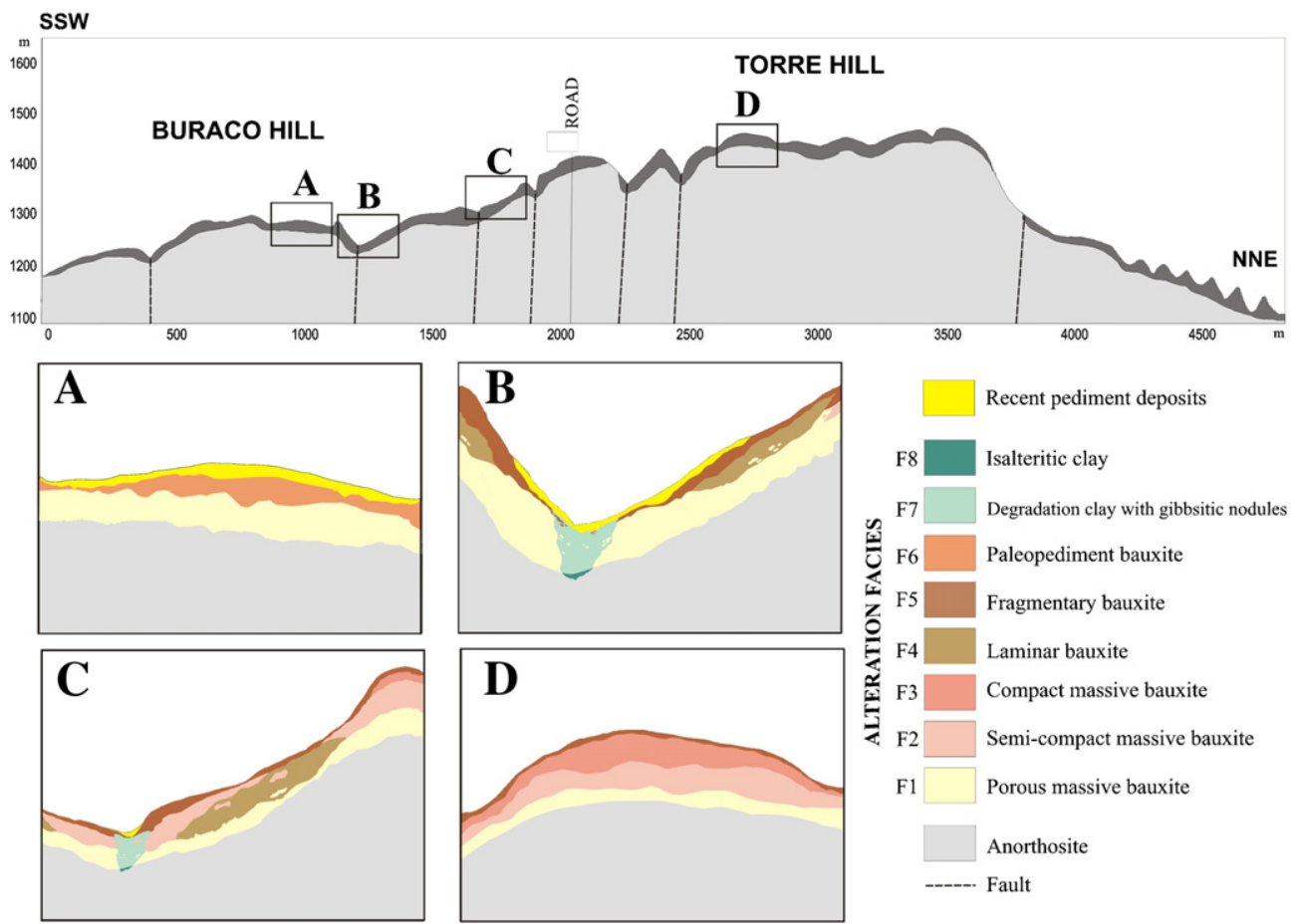

Fig. 2. Alteration facies and their location in the landscape of the bauxitic massif of Barro Alto. 


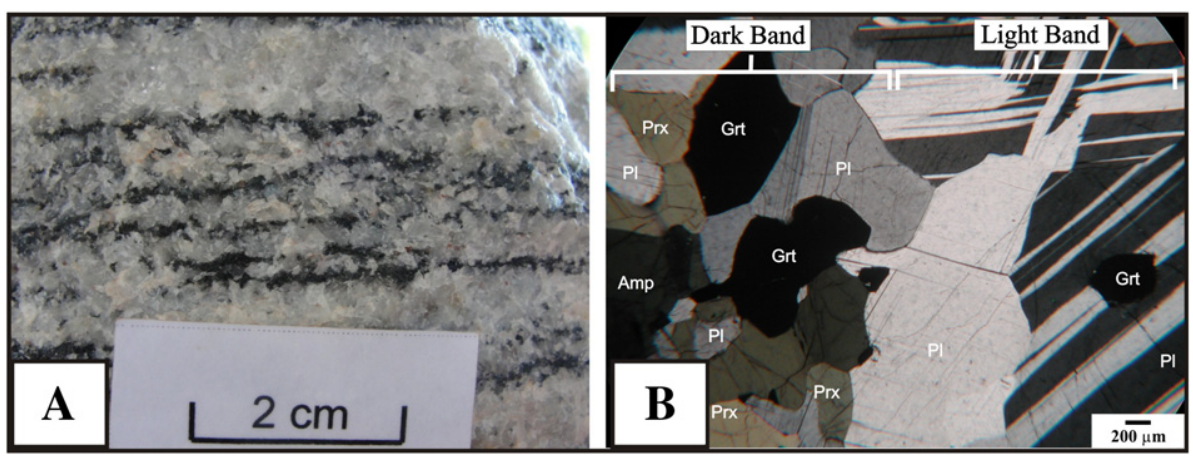

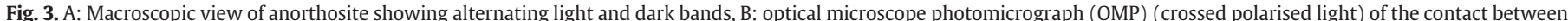
the light band and the dark band of anorthosite. $\mathrm{Pl}=$ plagioclase; $\mathrm{Grt}=$ garnet; Amp=amphibole; Prx= pyroxene.

\subsubsection{Fresh rock ( $R$ - anorthosite)}

Macroscopic characterisation of the anorthosite (Oliveira et al., 2011) shows a holocrystalline, inequigranular and medium- to coarse-grained texture. The colour of the anorthosite varies from grey to light pink, and its structure is composed of alternating light and dark bands with diffuse inter-band contact (Fig. 3A). Microscopically, the light bands (Fig. 3B) are primarily composed of bytownite (95\%). The dark bands (Fig. 3B) are composed mainly of garnet (30\%), amphibole (25\%), clino and orthopyroxene (20\%), bytownite (20\%) and accessory and secondary minerals $(<5 \%)$. The accessory minerals are spinel and titanites, and the secondary mineral is zeolite. The paragenesis of the mafic mineral assemblage indicates a high degree of metamorphism (granulite facies). The anorthosite exhibits a granoblastic polygonised texture and deformation features, such as twinned, minted, undulatory extinction and subgrains and fractures. The mean bulk density is $2.68 \mathrm{~g} / \mathrm{cm}^{3}$ (Table 2).

\subsubsection{Porous massive bauxite facies (F1)}

The F1 facies is isalteritic, directly contacts the anorthosite (Fig. 2) and is whitish with reddish to yellowish bands that formed from the alteromorphosis of the dark bands of the fresh rock (Fig. 4A). The mineralogical composition (Fig. 6) exhibits a predominance of gibbsite (from 90 to 95\%) and a minor content (5 to 10\%) of goethite that is concentrated in the reddish to yellowish bands. The mean bulk density is $1.48 \mathrm{~g} / \mathrm{cm}^{3}$ (Table 2).

Microscopically, high porosity is evident in F1. The voids exhibit dimensions ranging from micrometres to centimetres and shapes ranging
F1

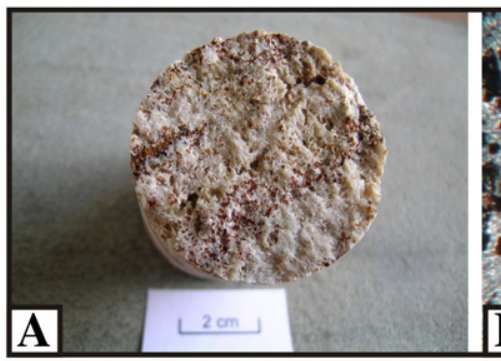

F2

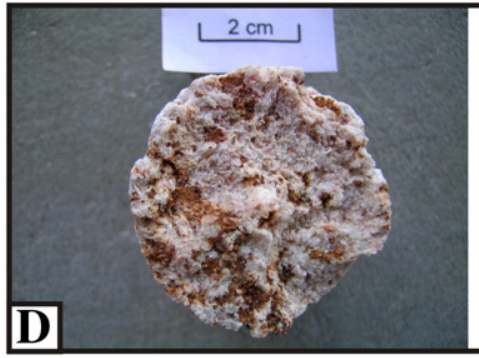

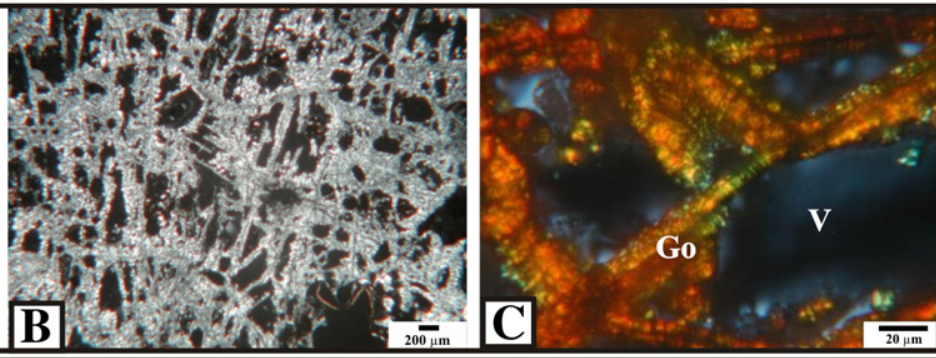
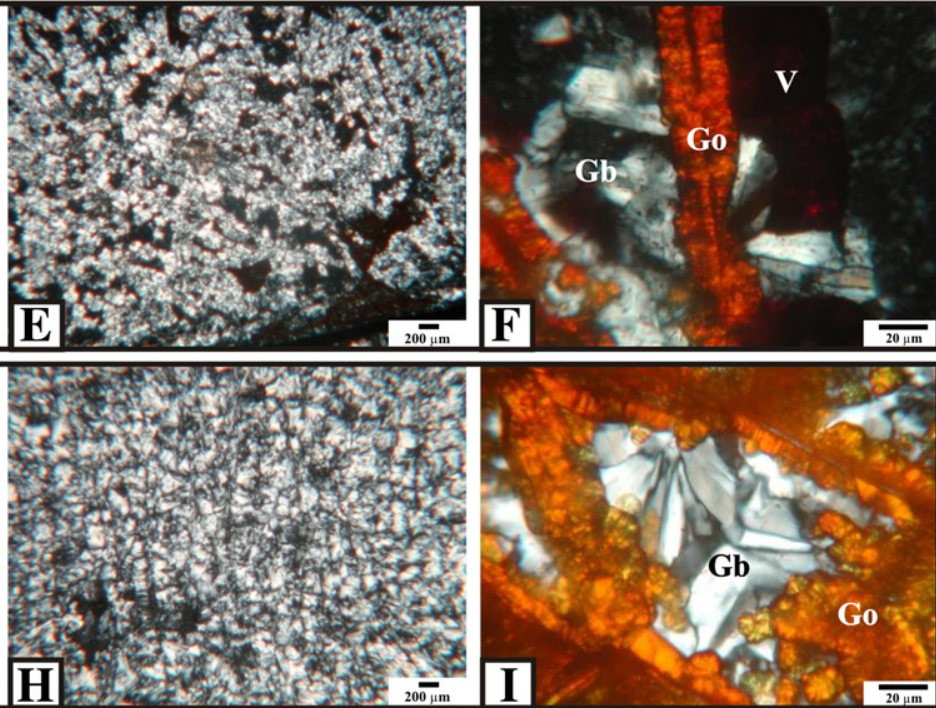

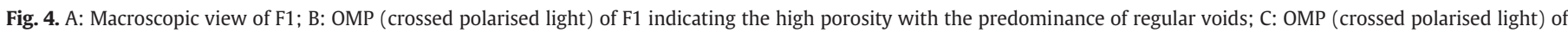

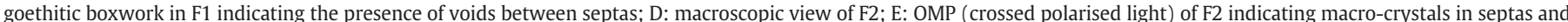

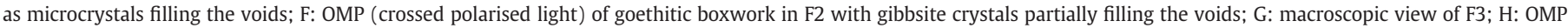

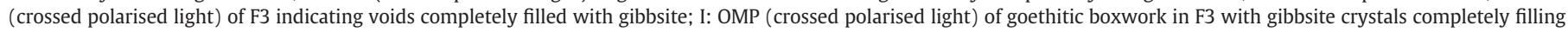
the voids. $\mathrm{Gb}=$ gibbsite; $\mathrm{Go}=$ goethite and $\mathrm{V}=$ void. 
Table 1

Chemical composition obtained by XRF of fresh rock (R) and the alteration facies (F) of bauxite from the Barro Alto.

\begin{tabular}{|c|c|c|c|c|c|c|c|c|c|c|c|c|}
\hline \multirow[b]{2}{*}{ Samples } & \multirow{2}{*}{$\frac{\mathrm{R}}{08}$} & \multirow{2}{*}{$\frac{\mathrm{F} 1}{25}$} & \multirow{2}{*}{$\frac{\mathrm{F} 2}{05}$} & \multirow{2}{*}{$\frac{\mathrm{F} 3}{05}$} & \multicolumn{2}{|l|}{ F4 } & \multicolumn{2}{|l|}{ F5 } & \multirow{2}{*}{$\frac{\mathrm{F} 6}{03}$} & \multirow{2}{*}{$\frac{\mathrm{F} 7_{\mathrm{T}}}{22}$} & \multirow{2}{*}{$\frac{\mathrm{F} 7_{\mathrm{B}}}{20}$} & \multirow{2}{*}{$\frac{\mathrm{F} 8}{01}$} \\
\hline & & & & & $10^{\mathrm{a}}$ & $03^{\mathrm{b}}$ & $07^{c}$ & $05^{\mathrm{d}}$ & & & & \\
\hline \multicolumn{13}{|l|}{ \% Weight } \\
\hline $\mathrm{SiO}_{2}$ & $45.46 \pm 0.43$ & $0.77 \pm 0.32$ & $0.45 \pm 0.20$ & $0.58 \pm 0.29$ & $0.73 \pm 0.39$ & $22.76 \pm 2.06$ & $1.09 \pm 0.46$ & $28.24 \pm 8.07$ & $5.55 \pm 1.85$ & $22.62 \pm 13.72$ & $42.58 \pm 2.75$ & 47.49 \\
\hline $\mathrm{TiO}_{2}$ & $0.10 \pm 0.01$ & $0.18 \pm 0.07$ & $0.25 \pm 0.03$ & $0.23 \pm 0.02$ & $0.15 \pm 0.07$ & $1.18 \pm 0.11$ & $0.17 \pm 0.07$ & $0.85 \pm 0.34$ & $0.12 \pm 0.07$ & $0.38 \pm 0.32$ & $0.46 \pm 0.26$ & 0.25 \\
\hline $\mathrm{Al}_{2} \mathrm{O}_{3}$ & $33.90 \pm 0.70$ & $61.20 \pm 1.36$ & $60.81 \pm 0.67$ & $60.98 \pm 0.90$ & $62.00 \pm 0.64$ & $41.12 \pm 3.86$ & $61.71 \pm 1.24$ & $44.00 \pm 3.73$ & $60.06 \pm 2.06$ & $49.74 \pm 7.57$ & $39.11 \pm 1.60$ & 35.83 \\
\hline $\mathrm{Fe}_{2} \mathrm{O}_{3}$ & $1.73 \pm 0.33$ & $3.13 \pm 1.85$ & $3.69 \pm 0.58$ & $3.49 \pm 1.99$ & $1.99 \pm 1.12$ & $7.97 \pm 0.75$ & $2.86 \pm 1.73$ & $5.69 \pm 1.78$ & $2.12 \pm 0.45$ & $2.73 \pm 1.64$ & $2.32 \pm 1.92$ & 2.08 \\
\hline $\mathrm{MnO}$ & $0.02 \pm 0.03$ & $<\mathrm{LQ}$ & $<\mathrm{LQ}$ & $<\mathrm{LQ}$ & $<\mathrm{LQ}$ & $0.01 \pm 0.00$ & $<\mathrm{LQ}$ & $0.01 \pm 0.00$ & $<\mathrm{LQ}$ & $0.01 \pm 0.00$ & $0.03 \pm 0.02$ & 0.05 \\
\hline $\mathrm{MgO}$ & $0.76 \pm 0.04$ & $0.10 \pm 0.04$ & $0.09 \pm 0.01$ & $0.10 \pm 0.01$ & $0.09 \pm 0.02$ & $0.08 \pm 0.01$ & $0.10 \pm 0.01$ & $0.10 \pm 0.00$ & $0.10 \pm 0.02$ & $0.08 \pm 0.01$ & $0.11 \pm 0.09$ & 0.46 \\
\hline $\mathrm{CaO}$ & $15.61 \pm 0.44$ & $<\mathrm{LQ}$ & $<\mathrm{LQ}$ & $<\mathrm{LQ}$ & $<\mathrm{LQ}$ & $<\mathrm{LQ}$ & $<\mathrm{LQ}$ & $<$ LQ & $<\mathrm{LQ}$ & $0.01 \pm 0.00$ & $0.04 \pm 0.09$ & 1.04 \\
\hline $\mathrm{Na}_{2} \mathrm{O}$ & $2.34 \pm 0.27$ & $<\mathrm{LQ}$ & $<\mathrm{LQ}$ & $<\mathrm{LQ}$ & $<\mathrm{LQ}$ & $<\mathrm{LQ}$ & $<\mathrm{LQ}$ & $<\mathrm{LQ}$ & $<\mathrm{LQ}$ & $<\mathrm{LQ}$ & $<\mathrm{LQ}$ & 0.01 \\
\hline $\mathrm{K}_{2} \mathrm{O}$ & $0.03 \pm 0.00$ & $<\mathrm{LQ}$ & $<\mathrm{LQ}$ & $<\mathrm{LQ}$ & $<$ LQ & $0.02 \pm 0.00$ & $<\mathrm{LQ}$ & $0.03 \pm 0.00$ & $<\mathrm{LQ}$ & $0.01 \pm 0.00$ & $0.02 \pm 0.01$ & 0.01 \\
\hline $\mathrm{P}_{2} \mathrm{O}_{5}$ & $<\mathrm{LQ}$ & $0.03 \pm 0.01$ & $0.04 \pm 0.02$ & $0.04 \pm 0.02$ & $0.04 \pm 0.02$ & $0.07 \pm 0.00$ & $0.03 \pm 0.00$ & $0.08 \pm 0.02$ & $0.02 \pm 0.01$ & $0.02 \pm 0.01$ & $0.03 \pm 0.02$ & 0.03 \\
\hline LOI & $0.52 \pm 0.10$ & $34.0 \pm 0.79$ & $\begin{array}{l}34.15 \pm \\
0.62\end{array}$ & $33.87 \pm 0.55$ & $34.38 \pm 0.80$ & $26.49 \pm 7.29$ & $33.67 \pm 0.81$ & $20.60 \pm 3.04$ & $32.10 \pm 1.27$ & $24.29 \pm 6.21$ & $15.35 \pm 1.04$ & 12.86 \\
\hline Total & 100.47 & 99.41 & 99.48 & 99.29 & 99.38 & 99.7 & 99.63 & 99.60 & 100.07 & 99.89 & 100.05 & 100.08 \\
\hline
\end{tabular}

$<\mathrm{LQ}=$ below detection limit; $\mathrm{LQ}=0.001 ; \pm$ standard deviation; $\mathrm{T}-$ top of the profile; $\mathrm{B}-$ bottom of the profile.

a Bauxite plates.

b Material between bauxite plates.

c Bauxite fragments.

d Pedogenetic material between bauxite fragments.

from rectangular to quadratic (Fig. 4B). The voids were derived from the total consumption of primary minerals. The structure is characterised by a crystalliplasma consisting of a network of gibbsite and goethite boxworks, similar to that presented by Nahon (1991) and Delvigne (1998), generating an isalteritic structure. The goethite septas forming the boxworks are separated by voids (Fig. 4C). The contact between the gibbsite and goethite boxworks is abrupt, with little or no iron dispersed in the matrix. This characteristic indicates that the gibbsite was formed first, then the goethite, which explains the light colour of this facies.

The chemical composition of the porous massive bauxite facies (Table 1 ) reflects the facies' mineralogical composition, exhibiting a high $\mathrm{Al}_{2} \mathrm{O}_{3}$ content ( $61.20 \%$ on average) and low concentrations of $\mathrm{Fe}_{2} \mathrm{O}_{3}$ and $\mathrm{SiO}_{2}$ (3.13\% and $0.77 \%$, respectively). The results of mass balance analysis indicate the loss of silica and alkalis (Table 2). There were no modifications in the $\mathrm{Al}$, Fe or Ti content, indicating a relative accumulation of these elements (Boulangé et al., 1987, 1990).

\subsubsection{Semi-compact massive bauxite facies (F2)}

Located over F1 (Fig. 2), F2 is whitish to slightly pink. Macroscopically, F2 shows many voids that are filled with microscopic and translucent gibbsite (Fig. 4D). The mean bulk density of F2 is $1.63 \mathrm{~g} / \mathrm{cm}^{3}$ (Table 2).

The micromorphological observations corroborate F2's macromorphological characteristics. Gibbsite is the predominant mineral (92 to 96\%), and it occurs as macro-crystals in septas and as microcrystals filling the voids (Figs. 6 and 4E). In the former case, the gibbsite crystals are organised from the edges towards the centres of the voids. Goethite ( 4 to $8 \%$ ) occurs in boxworks. Some boxworks exhibited destruction features, such as the dispersion of Fe or the formation of reddishbrown patches over gibbsite crystals. Gibbsite crystals partially fill the goethite boxworks (Fig. 4F). Microstructures caused by compaction via collapse, such as fractures and breaks, were not observed. Only crystalline features filled the pores, as observed by Boulangé and Colin (1994).

The F2 facies shows a high content of $\mathrm{Al}_{2} \mathrm{O}_{3}$ and a low content of $\mathrm{Fe}_{2} \mathrm{O}_{3}, \mathrm{TiO}_{2}$ and $\mathrm{SiO}_{2}$ (Table 1). The F2 mass balance related to $\mathrm{F} 1$ demonstrates enrichment in $\mathrm{Al}, \mathrm{Ti}, \mathrm{P}$ and $\mathrm{Fe}$ and continuous desilicification and alkali loss (Table 2).

The mineralogical and morphological similarities between F1 and F2 suggest a common formation mechanism, in which the voids of F1 were filled by aluminium solutions derived from the upper profile, forming F2. This arrangement supports verticalist concepts, where the development of products geochemically enriched by absolute accumulation occurs as a result of the remobilisation of elements from the top positions of the profile (Larizzatti and Oliveira, 2005; Nahon, 1986, 1991; Tardy, 1993).

\subsubsection{Compact massive bauxite facies (F3)}

This facies is compact, pinkish (Fig. 4G) and is situated over F2 in the profiles (Fig. 2). The predominant mineralogy is composed of gibbsite (92 to 100\%, Fig. 6) and the mean bulk density is $1.87 \mathrm{~g} / \mathrm{cm}^{3}$ (Table 2).

Table 2

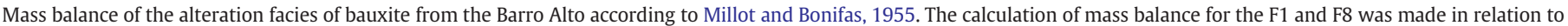
the mean value of the rock - R (anorthosite) and the F2, F3 and F7 facies in relation to the mean value of the porous bauxite (F1).

\begin{tabular}{|c|c|c|c|c|c|c|c|c|}
\hline & & $\mathrm{R}$ & F1 & F8 & F2 & F3 & $\mathrm{F} 7_{\mathrm{T}}$ & $\mathrm{F}_{\mathrm{B}}$ \\
\hline \multirow{3}{*}{$\begin{array}{l}\text { Bulk density } \\
\left(\mathrm{g} / \mathrm{cm}^{3}\right)\end{array}$} & Mean & 2.68 & 1.48 & 1.41 & 1.63 & 1.87 & 1.18 & 1.26 \\
\hline & Lower & 2.64 & 1.31 & 1.35 & 1.41 & 1.73 & 1.00 & 1.17 \\
\hline & Higher & 2.73 & 1.57 & 1.52 & 1.83 & 2.15 & 1.39 & 1.31 \\
\hline $\mathrm{Si}$ & & - & -99.06 & -45.03 & -35.63 & -1.54 & 2242.19 & 4607.86 \\
\hline $\mathrm{Ti}$ & & - & -0.59 & 31.52 & 52.96 & 61.44 & 68.31 & 117.56 \\
\hline $\mathrm{Al}$ & & - & -0.30 & -44.39 & 9.43 & 25.89 & -35.2 & -45.59 \\
\hline $\mathrm{Fe}$ & & - & -1.78 & -36.74 & 29.83 & 40.88 & -30.45 & -36.89 \\
\hline Mn & & - & -100 & 31.52 & 0 & 0 & 0.01 & 0.03 \\
\hline $\mathrm{Mg}$ & & - & -92.73 & -68.15 & -0.87 & -26.35 & -36.21 & -6.35 \\
\hline $\mathrm{Ca}$ & & - & -100 & -96.49 & 0 & 0 & 0.01 & 0.04 \\
\hline $\mathrm{Na}$ & & - & -100 & -99.77 & 0 & 0 & 0 & 0 \\
\hline K & & - & -100 & -82.46 & 0 & 0 & 0.01 & 0.02 \\
\hline $\mathrm{P}$ & & - & 136.67 & 200.63 & 46.84 & 68.46 & -46.84 & -14.86 \\
\hline
\end{tabular}

$\mathrm{T}-$ top of the profile; $\mathrm{B}-$ bottom of the profile. 


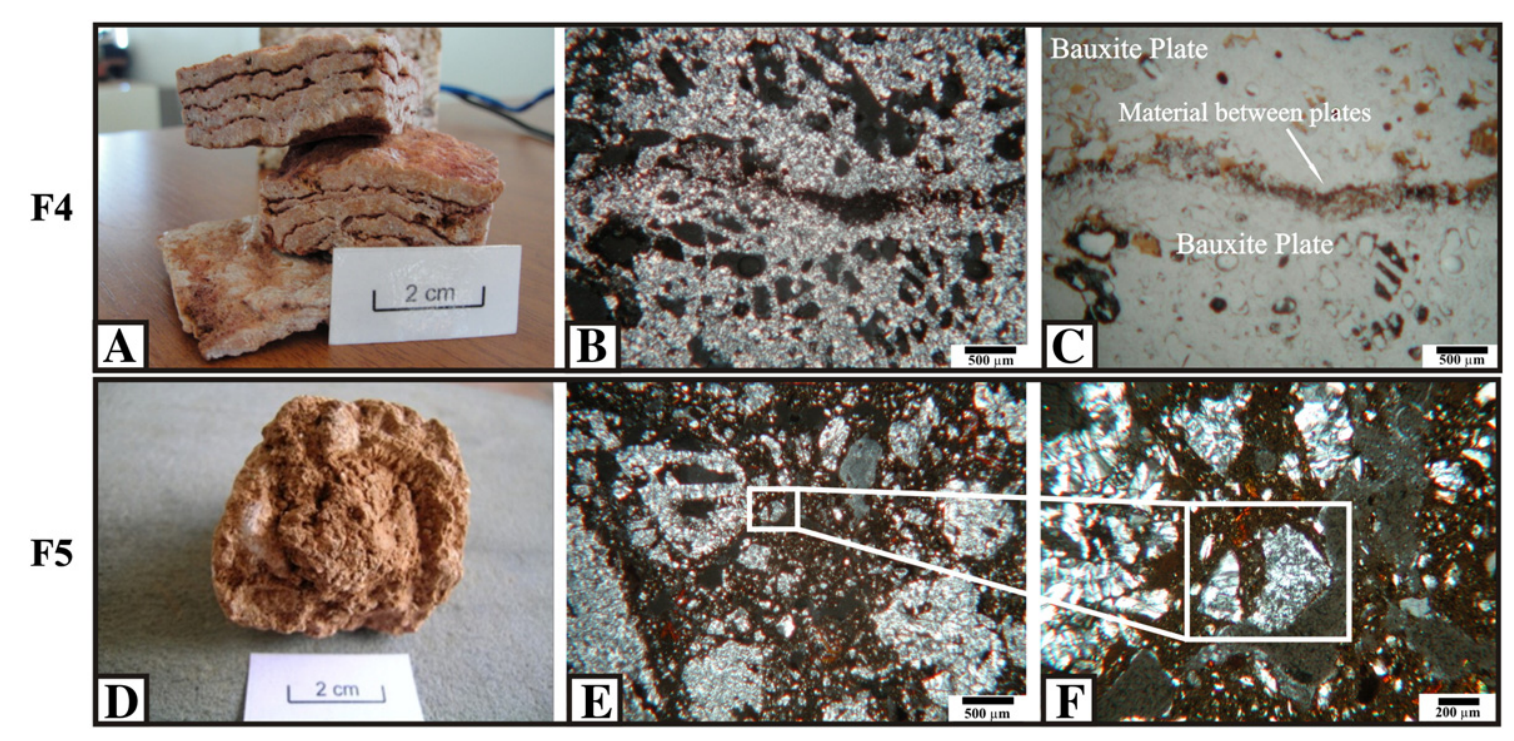

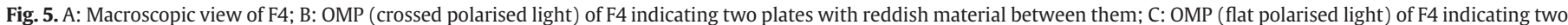

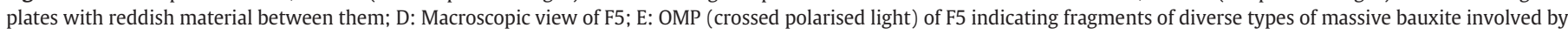
pedogenetic material; F: OMP (crossed polarised light) of F5 highlights angular bauxite fragment involved by yellowish-brown fine material with a speckled b-fabric.

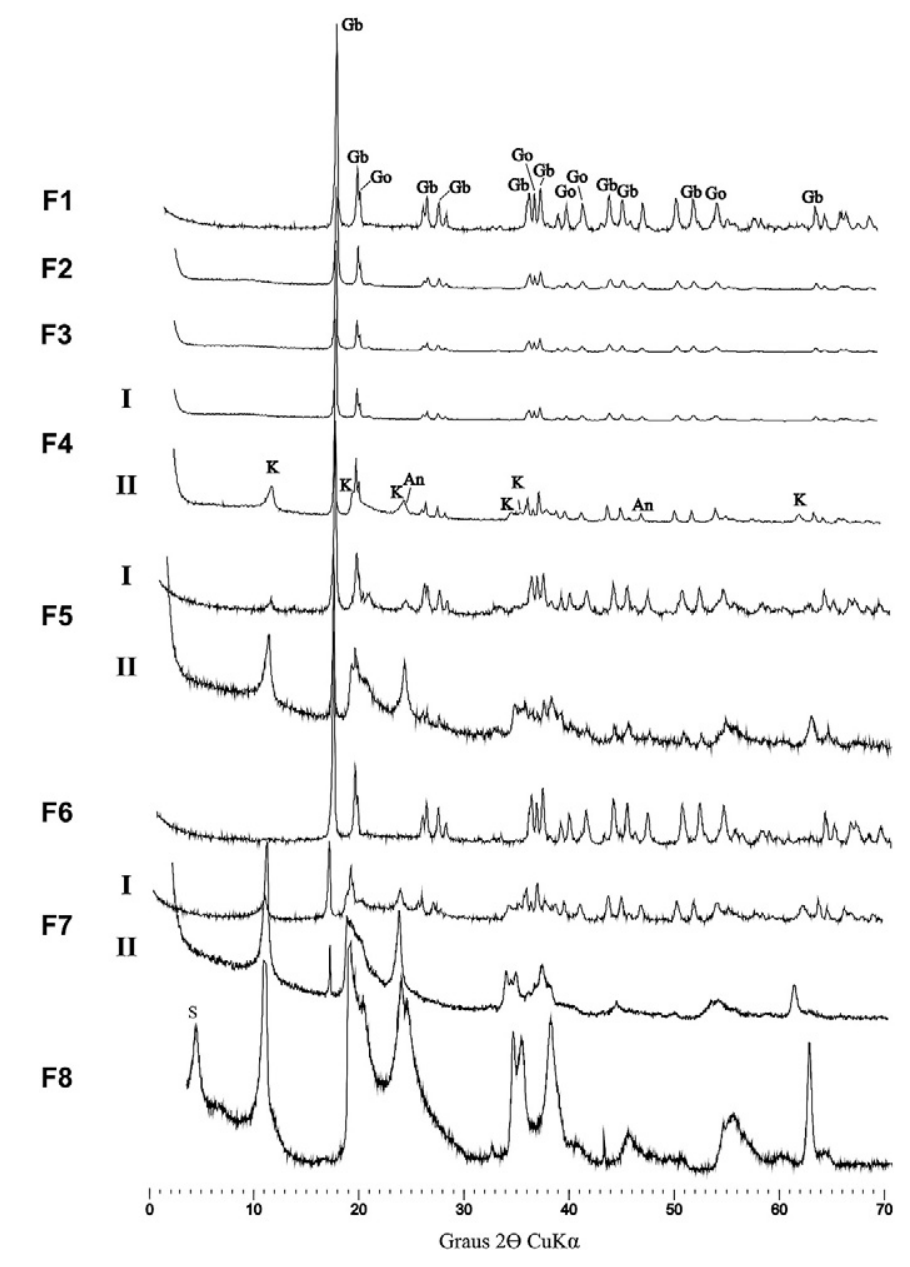

Fig. 6. X-ray diffraction patterns (CuK $\alpha$ radiation) of the F1, F2, F3, and F4 facies: I - bauxite plates, II - reddish material between plates; F5: I - bauxite fragments, II - pedogenetic material between fragments; F6, F7: I - degradation clay with gibbsitic nodules on the top of the profile, II - degradation clay with gibbsitic nodules on the bottom of the profile and F8. $\mathrm{Gb}=$ gibbsite; $\mathrm{Go}=$ goethite; $\mathrm{K}=$ kaolinite; $\mathrm{An}=$ anatase and $\mathrm{S}=$ smectite.
Micromorphologically, F3 has few voids with irregular shapes and without connectivity (Fig. $4 \mathrm{H}$ ), and it is almost completely filled with gibbsite. Goethite boxworks are scarce, never constituting more than $8 \%$ of the mineralogical composition, and are completely filled with gibbsite when they occur (Fig. 4I). Most of the Fe occurs as spots or dispersed dyeing gibbsite crystals.

F3 shows a high content of $\mathrm{Al}_{2} \mathrm{O}_{3}$ and a low content of $\mathrm{Fe}_{2} \mathrm{O}_{3}, \mathrm{TiO}_{2}$ and $\mathrm{SiO}_{2}$ (Table 1). Its mass balance shows an enrichment in $\mathrm{Al}$, Ti and Fe and a loss of Si and alkalis (Table 2).

These results suggest that F3 is the result of the continuation of the process that filled the pores of F2 with gibbsite, causing an absolute enrichment in aluminium and other residual elements such as iron and titanium.

\subsubsection{Laminar bauxite facies (F4)}

F4 occurs in the steep slopes of the massif (Fig. 2) and constitutes a fragmented horizon formed of pink plates of bauxite, where the dip direction is concordant with the slope. The plates have shaped waveforms and their thicknesses vary from $\mathrm{mm}$ to $\mathrm{cm}$. The plates are separated by a reddish material (Fig. 5A). The plates (Fig. 6) are predominantly composed of gibbsite (90\%) and goethite (10\%). However, mineralogically, the reddish material (Fig. 6) differs from the plates because of the presence of kaolinite ( 47.5 to $49 \%$ ) and traces of anatase ( $<1 \%$ ), in addition to gibbsite ( 38 to $42 \%$ ) and goethite (11 to $13.5 \%$ ).

The bauxite plates (Fig. $5 \mathrm{~B}$ and $\mathrm{C}$ ) are composed of a gibbsite crystalliplasma involving goethite boxworks. The reddish material between the plates presents a gloss matte and a speckled b-fabric without pedofeatures (Bullock et al., 1985).

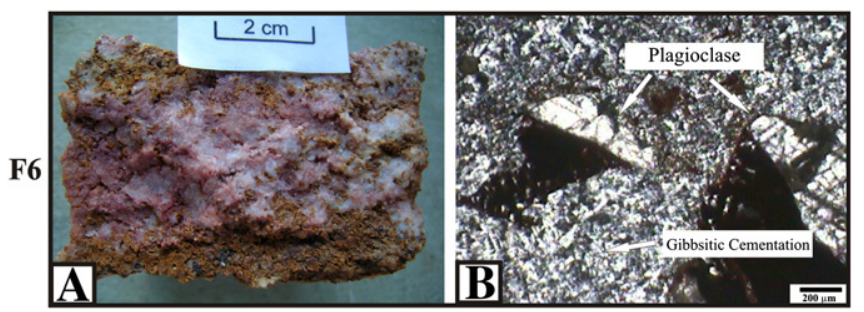

Fig. 7. F6: A - macroscopic view of F6; B - OMP (crossed polarised light) of F6, highlighting the fragmented plagioclase crystals involved in a gibbsitic cementation. 
The bauxite plates are high in $\mathrm{Al}_{2} \mathrm{O}_{3}$ but low in $\mathrm{SiO}_{2}, \mathrm{TiO}_{2}$ and $\mathrm{Fe}_{2} \mathrm{O}_{3}$ (Table 1). The reddish material has a high $\mathrm{SiO}_{2}$ (22.76\%) and $\mathrm{Al}_{2} \mathrm{O}_{3}$ (41.12\%) content and low $\mathrm{Fe}_{2} \mathrm{O}_{3}$ (7.97\%) and $\mathrm{TiO}_{2}$ (1.18\%) content.

The micromorphological, mineralogical and geochemical attributes of $\mathrm{F} 4$ show similarities to those of F1, F2 and F3, indicating that F4 is derived from the previous facies (the compact massive bauxite facies). The position of F4 in the profile and in the landscape suggests that the fragmentation of bauxite is associated with the steepness of the slopes because laminar bauxite occurs only on steep slopes, and there are no signs that suggest that the plates have been moving. In this case, the movement of water along the slope led to the preferential remobilisation of iron along steep areas. When there is a loss of iron, the duricrust loses cohesiveness and is easily fragmented (Hieronymus et al., 1999).

\subsubsection{Fragmentary bauxite facies (F5)}

F5 occurs throughout the massive surface at the top of the profiles (Fig. 2). The fragments are angular to sub-round and pinkish, sized between 0.1 and $10 \mathrm{~cm}$, without an alteration cortex and surrounded by a pedogenetic brownish (5YR5/6) material (Fig. 5D). The number of fragments in the profiles decreases from top to the bottom, and the size of the fragments increases towards the bottom. Gibbsite is the predominant mineral (90 to 95\%) (Fig. 6), and traces of kaolinite were identified $(<3 \%)$. The pedogenetic material surrounding the fragments is formed by gibbsite ( 22 to $35 \%$ ), kaolinite ( 55 to $70 \%$ ), goethite (6-8\%) and anatase $(<1 \%)$ (Fig. 6).

Microscopically, the fragments are also angular to sub-round and are composed of various types of massive bauxite (such as semi-compact, compact and laminar) from the underlying facies (Fig. 5E and F). These fragments are dispersed in the fine material. F5 does not show a grade of pedality (Bullock et al., 1985). The groundmass is composed of yellowish-brown fine material with a speckled b-fabric. No skeleton grains were observed in the coarse material of the groundmass. There are simple packing void systems and crystalliplasma in some bauxite fragments.

The bauxite fragments have a high content of $\mathrm{Al}_{2} \mathrm{O}_{3}(61.71 \%)$ and a low content of $\mathrm{SiO}_{2}, \mathrm{TiO}_{2}$ and $\mathrm{Fe}_{2} \mathrm{O}_{3}$ (1.06, 0.17 and $2.86 \%$, respectively). In comparison, the pedogenetic material has a higher content of $\mathrm{SiO}_{2}$, $\mathrm{Fe}_{2} \mathrm{O}_{3}$ and $\mathrm{TiO}_{2}$ (28.24, 0.85 and 5.69\%, respectively) and a lower content of $\mathrm{Al}_{2} \mathrm{O}_{3}$ (44\%) (Table 1 ).

The results suggest that the genesis of $\mathrm{F} 5$ is related to the fragmentation of the underlying massive bauxite facies (e.g., semi-compact, compact and laminar). This fragmentation may be related to the existence of fractures due to the influence of tectonics and physical weathering caused by roots that promote the preferential movement of water, as shown by many studies (Beauvais, 2009; Eggleton and Taylor, 2008; Hao et al., 2010; Laskou and Economou-Eliopoulos, 2007; Nahon, 1991; Schwars, 1996; Tardy, 1993; Thomas, 1994). Initially, cavities and holes were formed, isolating the boulders, which became fragmented into smaller, angular pieces due to mechanical breakdown. These fragments were geochemically degraded and will become rounded, to constitute typical nodules (Bullock et al., 1985), until they are completely digested by pedogenetic processes and transformed into soils. Beauvais (2009) identified a facies similar to F5 in Central Africa that was associated with the degradation of a ferricrete and called the facies a ferricrete disaggregation horizon (ferricrete relicts + nodules + matrix).

\subsubsection{Bauxite palaeopediment facies (F6)}

F6 occurs at Buraco Hill under the pediment deposit (Fig. 2) and is formed by blocks and boulders surrounded by a pinkish clayey matrix. The contact between the fragments and matrix is diffuse, with clayey material within the boulders. The blocks and boulders include fragments of different types of bauxite (F1-F4 facies) connected by gibbsitic cement. Macroscopically, it is possible to detect fragments of the porous, compact and laminar pinkish bauxite facies in addition to the ferruginous zones (Fig. 7A). The mineralogical composition of this facies (Fig. 6) demonstrates the presence of gibbsite (90 to $94 \%$ ), kaolinite $(<6 \%$ ), goethite $(3-4 \%)$ and anatase $(<1 \%)$.

Micromorphological analysis reveals the presence of cores with various bauxitic microstructures that are similar to those of F1, F2 and F3. These cores are surrounded by microcrystalline gibbsite, with an abrupt contact between them. Fragmented plagioclase crystals occur locally and are involved in the same gibbsitic cementation (Fig. 7B).

Chemical analysis reveals that the percentage of $\mathrm{SiO}_{2}$ is slightly higher than that recorded for the massive bauxite facies (5.55\%) and that the $\mathrm{TiO}_{2}$ content and $\mathrm{Fe}_{2} \mathrm{O}_{3}$ content are slightly lower (Table 1).

The mineralogical, geochemical and morphological attributes of F6 and its position in the landscape suggest that it was formed from an ancient pediment that was cemented by a microcrystalline gibbsite forming the bauxite palaeopediment facies.

\subsubsection{Degradation clay with gibbsitic nodule facies (F7)}

F7 can be found in the concave areas of the massif, especially in the foothills of the slopes (Fig. 2). It is pinkish, sometimes with whitish parts, at the top (Fig. 8A) and whitish with pink areas and residual dots at the bottom (Fig. 8D). Fragments of bauxite and gibbsite crystals

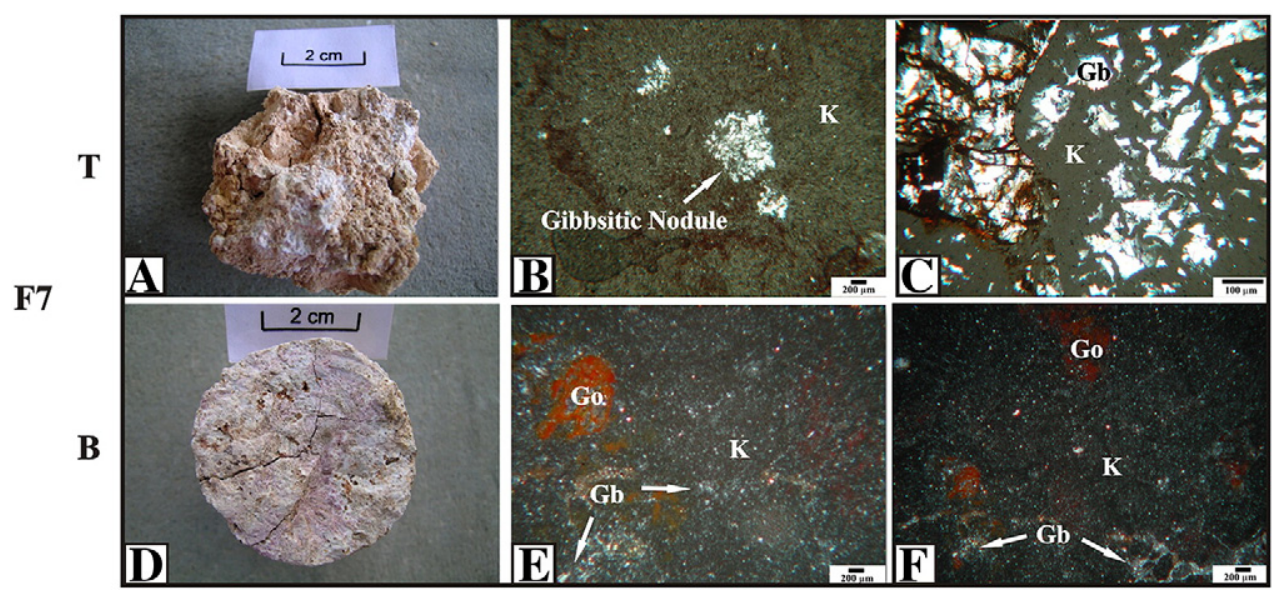

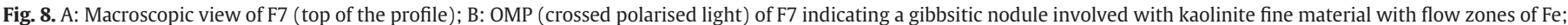

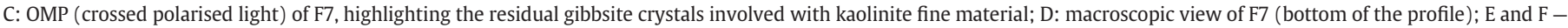

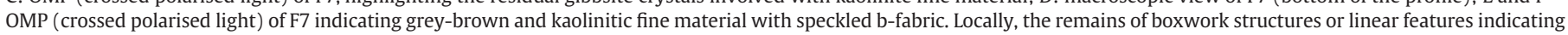
Fe dispersion occur. $\mathrm{Gb}=$ gibbsite; $\mathrm{Go}=$ goethite and $\mathrm{K}=$ kaolinite. 
F8

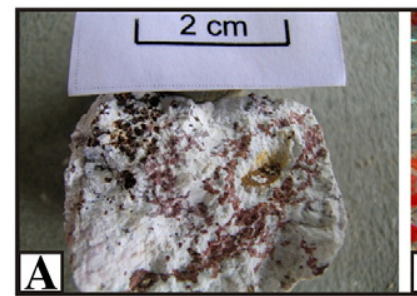

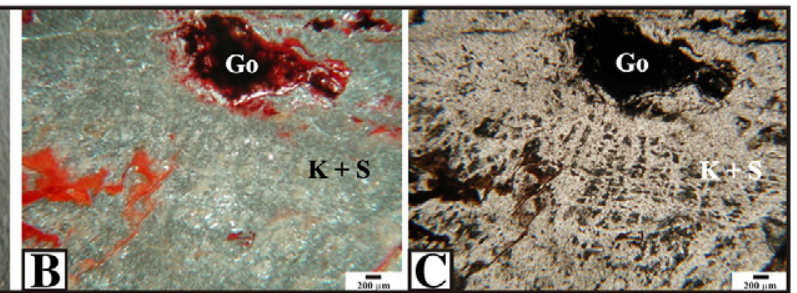

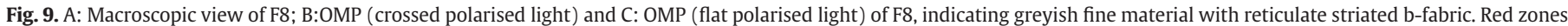
occur that are clearly marked (goethite boxworks), indicating the remains of ferromagnesian minerals. Go=goethite, $\mathrm{K}=$ kaolinite and $\mathrm{S}=$ smectite.

are frequent and well preserved at the top and gradually decrease in size and quantity towards the bottom, where they also become friable and crumbly. These fragments and crystals are disseminated in a clay matrix that becomes dominant towards the base. At the top, the mineralogical composition (Fig. 6) is predominantly gibbsite (70 to 89\%) and secondarily has a variable content of kaolinite (6 to $28 \%$ ), goethite (1 to $5 \%$ ) and anatase (1 to $2 \%$ ). The gibbsite content gradually decreases towards the base ( 0 to $6 \%$ ), while the kaolinite content increases until it becomes the predominant mineral ( $>80 \%$ ) (Fig. 6 ). The goethite usually occurs at concentrations of up to $4 \%$ and the anatase distribution ranges between 1 and $2 \%$. The mean bulk density is $1.18 \mathrm{~g} / \mathrm{cm}^{3}$ and $1.26 \mathrm{~g} / \mathrm{cm}^{3}$ at the top and base, respectively (Table 2).

Micromorphologically, F7 consists of brownish (top; Fig. 8B) to greybrown (base; Fig. 8E) kaolinitic fine material with speckled b-fabric. Scattered reddish areas can be observed, indicating an Fe distribution that is the result of the degradation of goethitic boxworks. The pores are also scarce and isolated and exhibit vugh-type morphology. The pedological features are represented by gibbsitic nodules as digitate and disjointed morphological types (Bullock et al., 1985) in close association with the kaolinitic fine material (Fig. 8C). They are rare at the bottom, and when they occur, they are represented by small corroded gibbsite crystals embedded in the kaolinitic fine material (Fig. 8F) without any relation to cracks, voids and fractures that could indicate areas of preferential water circulation (Delvigne, 1998). The kaolinite crystals from the fine material have small sizes $(<20 \mathrm{~nm})$ and ill-defined outlines (Fig. 10A), suggesting a low crystal order (Brindley and Brown, 1980; Grim, 1968), typical of pedogenic origin (Santos et al., 2004; Singh and Gilkes, 1992; Varajão et al., 2001). This is also indicated by the smooth diffraction band in the range $20-25^{\circ} 2 \theta \mathrm{CuK} \alpha$ (Fig. 10B).

The chemical composition of F7 (Table 1 ) shows a variable content of $\mathrm{SiO}_{2}$ and $\mathrm{Al}_{2} \mathrm{O}_{3}$, indicating a variable mineralogical distribution of kaolinite and gibbsite. At the top, the content of $\mathrm{SiO}_{2}$ is lower than
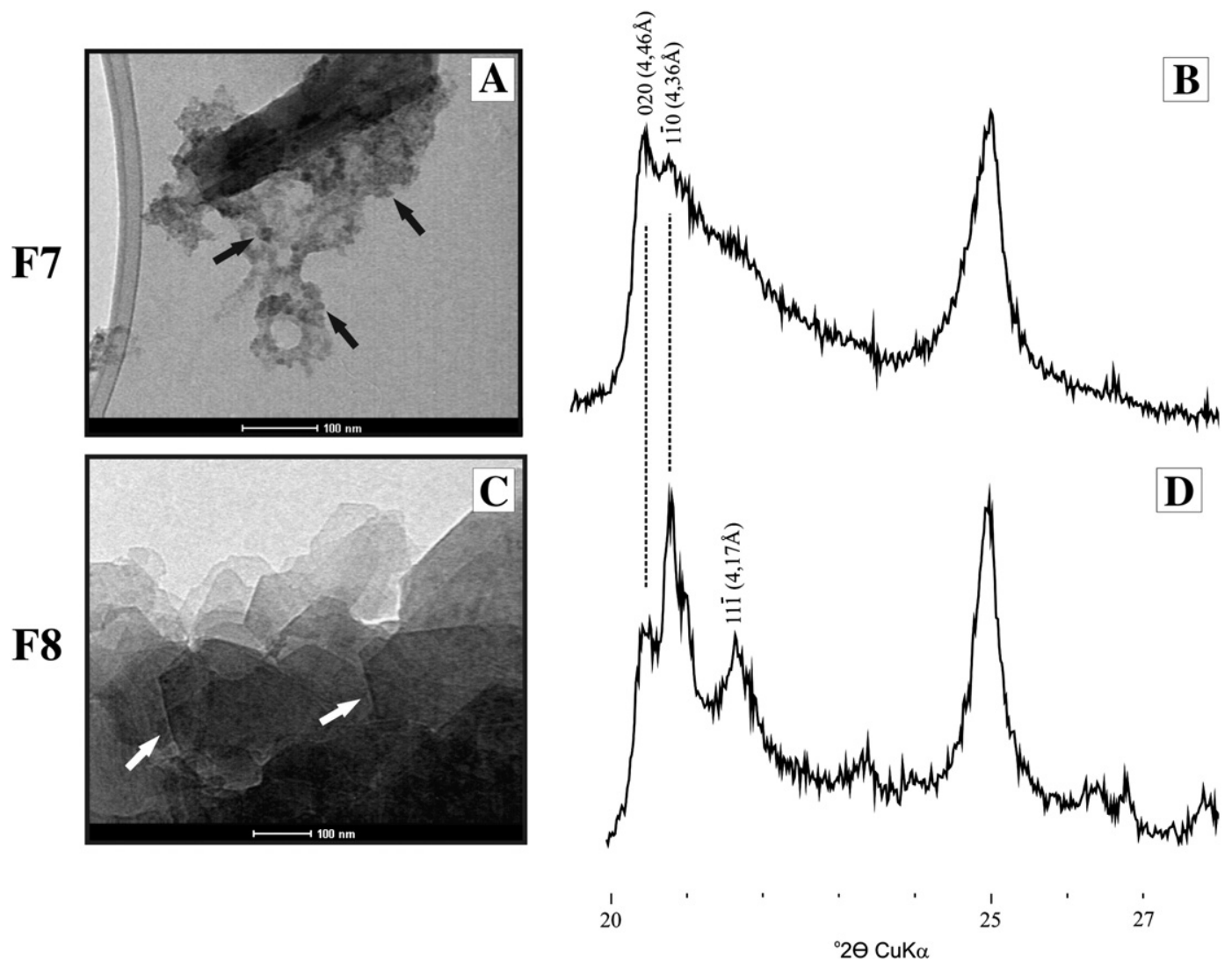

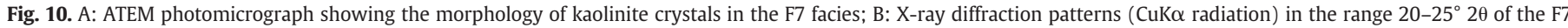

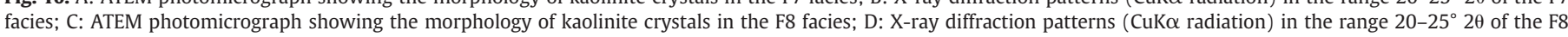
facies. 
$\mathrm{Al}_{2} \mathrm{O}_{3}$ (means of $22.62 \%$ and $49.74 \%$, respectively) while on the bottom this relationship is reversed (means of $42.58 \%$ and $39.11 \%$, respectively). The $\mathrm{Fe}_{2} \mathrm{O}_{3}$ content and $\mathrm{TiO}_{2}$ content at the top and bottom are similar (Table 1 ), and the high standard deviation for these elements reflects their heterogeneous distribution. The mass balance (relative to the composition of F1) shows the enrichment in silica and Ti (Table 2). This enrichment is higher at the bottom than at the top. However, the amounts of $\mathrm{Fe}$ and $\mathrm{Al}$ were reduced. The mass balance calculation of F7 was performed in relation to F1 because, according to Millot and Bonifas (1955), the analysis of losses and gains should consider the products and their source materials. In this study, the porous bauxite would be the source material, not the anorthosite.

The results suggest that F7 is derived from the geochemical degradation of bauxite facies, in this case, through the resilicification process, as previously described (Bocquier et al., 1982; Boulangé, 1984; Boulangé and Bocquier, 1983; Valenton, 1974; Varajão et al., 1989, 1990). The degradation and resilicification processes occur intensely at the base caused by the oscillation of the water table where the drainage flow is slow, providing saturated conditions, which leads to Si concentration. Towards the top, where drainage conditions are less saturated, the intensification of both processes gradually decreases, preserving fragments of bauxite.

\subsubsection{Isalteritic clay facies (F8)}

Isalteritic clay facies (F8) are not frequent, and they occur in direct contact with anorthosite (Fig. 2). Macroscopically, F8 shows a structure similar to that of protoliths with preserved reddish lineations (Fig. 9A). Mineralogically, F8 is composed of kaolinite (91\%), smectite (5\%) and goethite (4\%) (Fig. 6). There is no trace of gibbsite.

Micromorphologically (Fig. 9B and C), F8 shows a greyish fine material with reticulate striated b-fabric (Bullock et al., 1985). Red zones are clearly marked, indicating the remains of ferromagnesian minerals. The porous system is characterised by abundant vughs with some connectivity, suggesting an evolution into planar voids. It appears that such vughs occur in areas previously occupied by plagioclases that have been consumed (Bullock et al., 1985). Under TEM (Fig. 10C), the kaolinite particle sizes from the fine material are larger (>200 nm) and have more well-defined outlines than the kaolinite particles of the preceding facies (F7), which are smaller and malformed. This is also indicated by the good definition of the XRD pattern in the $20-25^{\circ} 2 \theta$ CuK $\alpha$ (Fig. 10D), suggesting a well-ordered kaolinite (Brindley and Brown, 1980; Grim, 1968).

The chemical composition (Table 1) of this facies shows a $\mathrm{SiO}_{2}$ content (47.49\%) higher than that of $\mathrm{Al}_{2} \mathrm{O}_{3}$ (35.83\%) and low concentrations of $\mathrm{Fe}_{2} \mathrm{O}_{3}$ and $\mathrm{TiO}_{2}$ (Table 1). Considering the content of $\mathrm{Al}$ and $\mathrm{Si}$ in the parent rock, the mass balance of F9 showed losses that are not statistically valid (Table 2 ).

The results suggest that F8 is formed by the direct weathering of anorthosite and is therefore classified as an isalteritic clay.

\subsubsection{Pediment deposits}

Pediment deposits are formed at the bottom of the hillslopes (Fig. 2) due to the erosion and transportation of the various types of fragmented bauxite.

\section{Discussion}

The relationships between the alteration facies, based on their mineralogical, geochemical and micromorphological properties, are presented in Fig. 11.

The first stage consists in weathering of anorthosite (Oliveira et al., 2011) through the alitisation process, forming the massive porous bauxite (F1). The formation of F1 involved the alteromorphosis of minerals from fresh rock, the loss of alkalis and silica and the relative accumulation of aluminium, generating the isalteritic structure with isovolumetric alteration. It is well known that such a process occurs under hot and very wet weather conditions (Tardy, 1992). Several studies (Beauvais et al.,
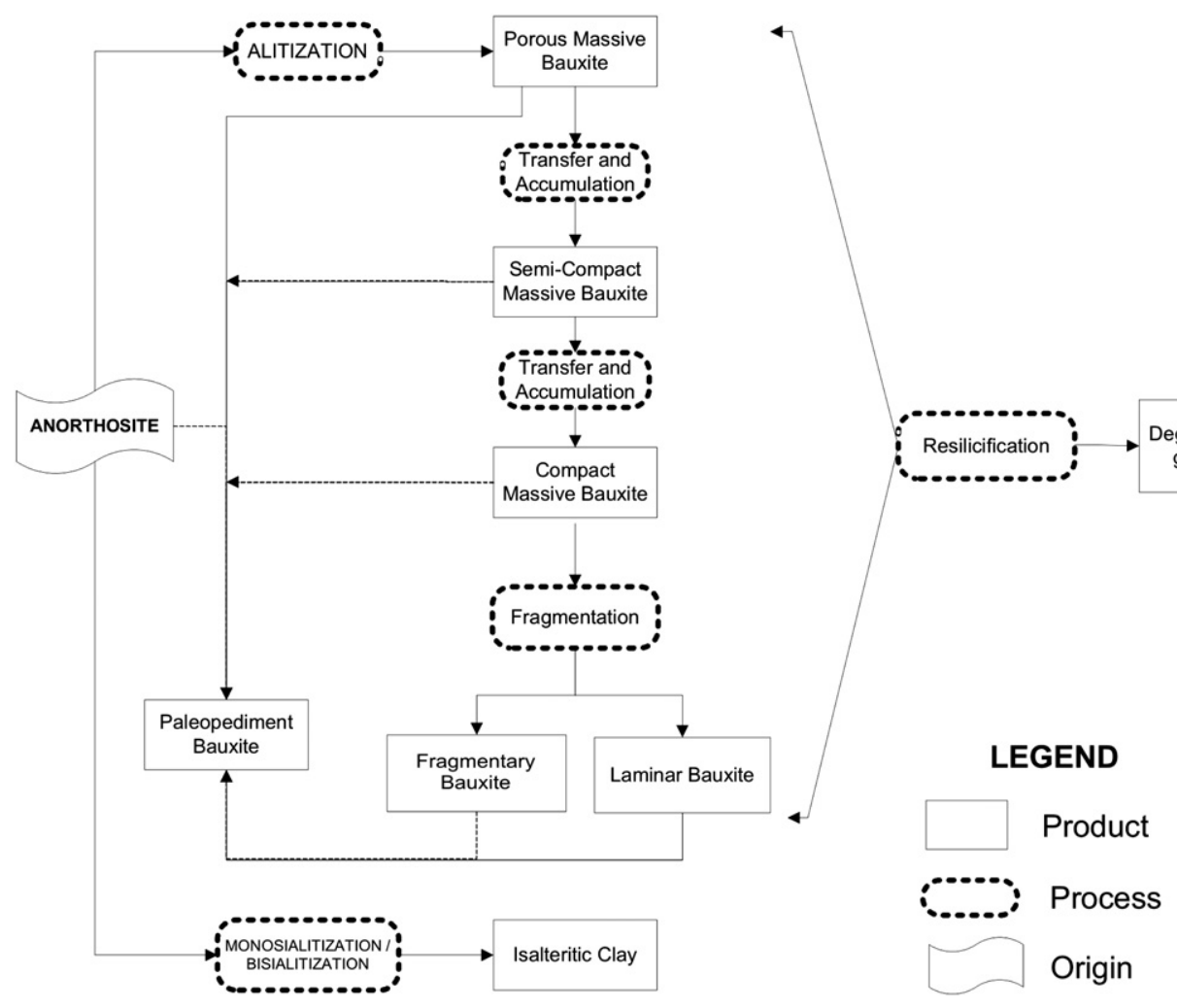

Fig. 11. Flow chart showing the relationships between the alteration facies. 
2008; Colin et al., 2005; Spier et al., 2006; Tardy et al., 1991; Varajão et al., 2009), including some using absolute dating and palaeoenvironmental reconstruction by continental drift, have shown that these weather conditions occurred during the Eocene. Such evidence suggests that the F1 facies was formed during the Eocene over a Cretaceous surface ranging from 1300 to 1500 m (Braun, 1971; King, 1956).

Changes of the F1 facies involved the transfer and accumulation of aluminium rich solutions through the profile and are responsible for the pore-filling by gibbsite, which transformed the $\mathrm{F} 1$ facies into semi and compact bauxite facies (F2 and F3). Modifications of the F1, F2 and F3 facies occurred in two ways: I - root activity formed fragments surrounded by pedogenetic matrix (F5); and II - intense water percolation in the steep slopes promoted the bauxite plates (F4).

Tectonic activity from the Late Eocene to the Oligocene (Riccomini and Assumpção, 1999; Saadi et al., 2005) has reactivated the sub-vertical faults (Fig. 2), altering the morphology of slopes and creating concavities in the hill. During these periods, less humid conditions led to the mechanical erosion and deposition of the bauxite fragments, forming the pediment deposits (F6).

With the return of humid conditions in the Miocene (Spier et al., 2006; Tardy et al., 1991), the laterisation process was restarted with the continuity of the facies (F2, F3, F4 and F5) transformations in the protuberant areas of the hill. In the concavities, variations in the hydrological conditions, such as drainage retention and oscillation of the water table, promoted the absolute silica enrichment from the bottom to the top of the profile, causing the geochemical degradation of bauxite and the transformation of the gibbsite into kaolinite (Bocquier et al., 1982; Boulangé, 1984; Boulangé and Bocquier, 1983), forming the F7 facies. Furthermore, the reincorporation of silica by vegetation decomposition on top of the profile has also been reported as being responsible for the resilicification of bauxites in several deposits (Lucas et al., 1993). The previous hydrological conditions also modified the type of process in the alteration front, from alitisation to monosialitisation and bisialitisation (Pedro, 1964), forming isalteritic clays (F8) from the anorthosite.

Under arid conditions in the Pliocene (Tardy et al., 1991), recent pediment deposits were formed, predominantly through mechanical erosion.

\section{Conclusions}

- The different alteration facies identified showed the polygenetic evolution of the Barro Alto bauxite.

- The main processes responsible for the evolution of Barro Alto bauxite are: I - transfer and accumulation of aluminium-rich solutions, with crystallisation of gibbsite in voids and the formation of compact facies; II - fragmentation associated with the mechanical activity of roots and water circulation in the slopes; and III - geochemical degradation and the transformation of gibbsite into kaolinite via the resilicification process, from the bottom to the top of the profiles.

- The mechanical resistance of the duricrust preserved the landscape responsible for the Cretaceous surface fossilisation. However, the concavities originated by faults modified the hydrological conditions of the profiles, generating changes in the alteration process and the degradation of bauxite facies.

- The mineralogical, geochemical and micromorphological characterisation of the facies enabled an understanding of the evolution of the Barro Alto bauxite, revealing the different lithotypes and their distribution in the landscape, which are of fundamental importance for bauxite ore exploitation.

\section{Acknowledgements}

The authors thank CNPq (Conselho Nacional de Desenvolvimento Científico e Tecnológico) and CAPES (Coordenação de Aperfeiçoamento de Pessoal de Nível Superior) for financial support. We are grateful to EDEM (Empresa de Desenvolvimento em Mineração e Participações
Ltda) for financial support and field assistance and providing analysis and samples.

\section{References}

Almeida, F.F.M., Hasui, Y., Brito Neves, B.B., Fuck, R.A., 1981. Brazilian structural provinces: an introduction. Earth-Science Reviews 17, 1-29.

Beauvais, A., 2009. Ferricrete biochemical degradation on the rainforest savannas boundary of Central African Republic. Geoderma 150, 379-388.

Beauvais, A., Ruffet, G., Hénocque, O., Colin, F., 2008. Chemical and physical erosion rhythms of the West African Cenozoic morphogenesis: the ${ }^{39} \mathrm{Ar}-{ }^{40} \mathrm{Ar}$ dating of supergene K-Mn oxides. Journal of Geophysical Research 113 (15 pp.).

Bocquier, G., Boulangé, B., Ildefonse, P., Nahon, D., Muller, D., 1982. Transfers, accumulation modes, mineralogical transformations and complexity of historical development profiles. II International Seminar on Laterization Held in São Paulo (Brazil), São Paulo. Proceedings, pp. 331-337.

Boulangé, B., 1984. Les formations bauxitiques latkntiques de Côte d'Ivoire. Les facies, leur transformation, leur distribution et l'évolution du modelt. Travaux et Documents de I'ORSTOM 175 (341 pp.)

Boulangé, B., Bocquier, G., 1983. Le rôle du fer dans la formation des pisolites alumineux au sein des cuirasses bauxitiques latéritiques. Sciences et Géologie, Strasbourg 1, 29-36.

Boulangé, B., Colin, F., 1994. Rare earth element mobility during conversion of nepheline syenite into lateritic bauxite at Passa Quatro, Minas Gerais, Brazil. Applied Geochemistry 9, 701-711.

Boulangé, B., Sigolo, J., Delvigne, J.E., 1987. Petrologia das concentrações absolutas e relativas em perfis de alteração laterítica: exemplo de enriquecimento supergeno de ferro e alumínio. Boletin Instituto de Geologia 18, 1-10.

Boulangé, B., Carvalho, A., Melfi, A., 1990. Geochemical characteristics of African and Brazilian bauxites deposits: $\mathrm{SiO}_{2}-\mathrm{Al}_{2} \mathrm{O}_{3}-\mathrm{Fe}_{2} \mathrm{O}_{3}$ system and $\mathrm{Ti}, \mathrm{Cr}, \mathrm{V}$ and $\mathrm{Fe}_{2} \mathrm{O}_{3}$ relations. 2nd International Symposium of Geochemistry of the Earth's Surface and of Mineral Formation, Aix: Chemical Geology, pp. 30-32.

Brasil, Ministério das Minas e Energia, Departamento Nacional da Produção de Minerais, Projeto RADAMBRASIL, 1981. Folhas SC.22 e SD.22: geologia, geomorfologia, pedologia, vegetação e uso potencial da terra. Rio de Janeiro, v. 22 e 25 (524 pp.).

Braun, O.P.G., 1971. Contribuição à geomorfologia do Brasil Central. Revista Brasileira de Geografia 32, 3-39.

Brindley, G.W., Brown, G., 1980. Crystal Structures of Clay Minerals and Their X-ray Identification (Monograph 5). Min. Soc., London (495 pp.)

Bullock, P., Fedoroff, N., Jongerius, A., Stoops, G., Tursina, T., Babel, U., 1985. Handbook for Soil Thin Section Description. Waine Research Publications, Wolverhampton (152 pp.).

Colin, F., Beauvais, A., Ruffet, G., Hénocque, O., 2005. First ${ }^{40} \mathrm{Ar} /{ }^{39} \mathrm{Ar}$ geochronology of lateritic manganiferous pisolites: implications for the Palaeogene history of a West African landscape. Earth and Planetary Science Letters 238, 172-188.

Correia, C.T., Girardi, V.A.V., Basei, M.A.S., Nutman, A., 2007. Cryogenian U-Pb (SHRIMP I) zircon ages of anorthosites from the upper sequences of Niquelândia and Barro Alto Complexes, Central Brazil. Revista Brasileira de Geociências 37, 70-75.

Delvigne, J.E., 1998. Atlas of Micromorphology of Mineral Alteration and Weathering 3rd. Canadian Mineralogist Special Publication, Ottawa (509 pp.).

Eggleton, R.A., Taylor, G., 2008. Effects of some macrobiota on the Weipa Bauxite northern Australia. Australian Journal of Earth Sciences 55, 71-82.

Grim, R.E., 1968. Clay Minerals, 2nd ed. McGraw-Hill, New York (596 pp.).

Hains, D.H., 2005. Competent person's report on Port Loko bauxite deposit in Sierra Leone. http://www.moydow.com/AIM_Rule26/CPR_Port_Loko.pdf.

Hao, X., Kwunlun, L., Wang, R., Sun, W., Li, Y., 2010. The geomicrobiology of bauxite deposits. Geoscience Frontiers 1, 81-89.

Hieronymus, B., Kotschoubey, B., Godot, J.-M., Boulègue, J., 1999. Evolução atual da cobertura laterítico-bauxítica da serra de Trucará, baixo rio Tocantins, Pará. Revista Brasileira de Geociencias 29 (4), 649-656.

King, L.C., 1956. A Geomorfologia do Brasil Oriental. Revista Brasileira de Geografia 18, $147-265$.

Larizzatti, J.H., Oliveira, S.M.B., 2005. Evolução Geoquímica e Balanço de Massa na Formação e Degradação de Perfis Lateríticos Encouraçados na Área da Fazenda Pison, Vale Do Rio Tapajós, Amazônia Central. Revista Brasileira de Geociencias 35 (2), 273-284.

Laskou, M., Economou-Eliopoulos, M., 2007. The role of micro-organisms on the mineralogical and geochemical characteristics of the Parnassos-Ghiona bauxite deposits, Greece. Journal of Geochemical Exploration 93, 67-77.

Lucas, Y., Luizão, F.J., Chauvel, A., Rouiller, J., Nahon, D., 1993. The relation between biological activity of the rainforest and mineral composition of the soils. Science 260, 521-523.

Melfi, A.J., 1997. Brazilian bauxite deposits: a review, In: Carvalho, A., Boulangé, B., Melfi, A.J., Lucas, Y. (Eds.), Brazilian Bauxites, 1rd ed. USP/FAPESP/ORSTOM, São Paulo, pp. 3-22.

Millot, G., Bonifas, M., 1955. Transformations isovolumetriques dans les phenomenes de laterisation et de bauxitisation. Bulletin Service Carte Géolique Alsace et Lorraine 8, 3-10.

Munsell, 1975. Munsell Soil Color Charts. Munsell Color Company, Baltimore.

Nahon, D.B., 1986. Evolution of iron crust in tropical landscape. In: Coleman, S.M. Dethier, D.P. (Eds.), Rates of Chemical Weathering of Rocks and Minerals. Academic Press, London, pp. 169-191.

Nahon, D.B., 1991. Introduction to the Petrology of Soils and Chemical Weathering. John Wiley and Sons, New York (313 pp.). 
Oliveira, F.S., Varajão, A.F.D.C., Varajão, C.A.C., Boulangé, B., Costa, J.L.G., Vessani, L.A 2009. Alteração supergênica e morfogênese tropical no Complexo MáficoUltramáfico Acamadado de Barro Alto, GO. Geociências 28, 255-272.

Oliveira, F.S., Varajão, A.F.D.C., Varajão, C.A.C., Boulangé, B., Gomes, N.S., 2011 Bauxitisation of anorthosites from Central Brazil. Geoderma 167-168, 319-327.

Pedro, G., 1964. Contribution à l'étude expérimentale de altération chimique dês roches cristallines. PhD Thesis, Faculté des Sciences Paris, Paris, 344 pp.

Pimentel, M.M. Ferreira Filho, C.F., Amstrong, R.A., 2004. SHRIMP U-Pb and Sm-Nd ages of the Niquelândia layered complex: Meso (1.25 Ga) and Neoproterozoic (0.79 Ga) extensional events in central Brazil. Precambrian Research 132, 132-135.

Reis, L.G.R., 2007. Goiás: investimentos em novos projetos superam US\$ 2 bilhões. Revista Brasil Mineral 258, 28-37.

Riccomini, C., Assumpção, M., 1999. Quaternary tectonics in Brazil. Episodes 22 221-225.

Saadi, A, Bezerra, F.H.R. Costa, R.D., Igreja, H.L.S., Franzinelli, E, 2005. Neotectônica da Plataforma Brasileira. In: Souza, C.R.G., Suguio, K., Oliveira, A.M.S., Oliveira, P.E. (Eds.), Quaternário do Brasil. Ribeirão Preto, Holos, pp. 211-234.

Santos, M.C., Varajão, A.F.D.C., Yvon, J., 2004. Genesis of clayey bodies in Quadrilátero Ferrífero, Minas Gerais, Brazil. Catena 55, 277-291.

Schwars, T., 1996. Distribution and genesis of bauxite on the Mambilla Plateau, Nigeria. Applied Geochemistry 12, 119-131.

Singh, B., Gilkes, R.J., 1992. Properties of soil kaolinites from south-western Australia. Journal of Soil Science 43, 645-647.

Spier, C.A., Vasconcelos, P.M., Oliveira, S.M.B., 2006. ${ }^{40} \mathrm{Ar} /{ }^{39} \mathrm{Ar}$ geochronological constraints on the evolution of lateritic iron deposits in the Quadrilátero Ferrífero, Minas Gerais, Brazil. Chemical Geology 234, 79-104.
Tardy, Y., 1992. Diversity and terminology of lateritic profiles. In: Martini, I.P., Chesworth, W. (Eds.), Weathering, Soils \& Paleosols. Elsevier, Amsterdam, pp. 379-406.

Tardy, Y., 1993. Pétrologie des latérites et des sols tropicaux. Masson, Paris (535 pp.).

Tardy, Y., Kobilsek, B., Paquet, H., 1991. Mineralogical composition and geographical distribution of African and Brazilian laterites. The influence of continental drift and tropical paleoclimates during the last 150 million years and implications for India and Australia. Journal of African Earth Sciences 12, 283-295.

Thomas, M. 1994. Tropical Geomorphology: A Study of Weathering on Landform Development in Warm Climate. John Wiley \& Sons, New York (313 pp.).

Valenton, I., 1974. Resilicification at the top of the foreland bauxite in Surinam and Guyana. Mineralium Deposita 9, 169-173.

Varajão, A.F.D.C., Boulangé, B., Melfi, A.J., 1989. The Petrological Evolution of the Facies in the Kaolinite and Bauxite Deposits of Vargem dos Óculos, Quadrilátero Ferrífero, Minas Gerais, Brazil: Trav. ICSOBA, 19, pp. 137-146.

Varajão, A.F.D.C. Boulangé, B. Melfi, A.J. 1990. Caracterizacão morfológica, mineralógica e química das fácies estruturais da jazida de caulinita de Vargem dos Óculos, Quadrilátero Ferrífero, MG. Revista Brasileira de Geociências 20, 75-82.

Varajão, A.F.D.C., Gilkes, R.J., Hart, R.D., 2001. The relationships between kaolinite crystal properties and the origin of materials for a Brazilian kaolin deposit. Clays and Clay Minerals 49, 44-59.

Varajão, C.A.C., Salgado, A.A.R., Varajão, A.F.D.C., Braucher, R., Colin, F., Nalini Jr., H.A., 2009. Estudo da evolução da paisagem do Quadrilátero Ferrífero (Minas Gerais, Brasil) por meio da mensuração das taxas de erosão $\left({ }^{10} \mathrm{Be}\right)$ e da pedogênese. Revista Brasileira de Ciência do Solo 33, 1409-1425.

Veiga, A.T.C., Girodo, A.C., 2008. Modelamento geológico e abordagem geoestatística da jazida de bauxita de Barro Alto - GO. Rel. Int. GEOS Consultoria, Brasil (157 pp.). 